\title{
Nutrient Retention Capacity of White and Red Varieties of Onion (Allium Cepa) Bulbs as Influenced by Storage Conditions
}

\author{
Shamsudeen Nassarawa Sanusi ${ }^{1}$, Mathew Kolawole Bolade ${ }^{2}$, Isaac Babatunde Oluwalana ${ }^{2}$ \\ ${ }^{1}$ Department of Food Science and Technology, Bayero University, Kano, Nigeria \\ ${ }^{2}$ Department of Food Science and Technology, Federal University of Technology, Akure, Nigeria
}

Email address:

mkbolade@futa.edu.ng (M. K. Bolade)

\section{To cite this article:}

Shamsudeen Nassarawa Sanusi, Mathew Kolawole Bolade, Isaac Babatunde Oluwalana. Nutrient Retention Capacity of White and Red Varieties of Onion (Allium cepa) Bulbs as Influenced by Storage Conditions. International Journal of Food Science and Biotechnology.

Vol. 3, No. 3, 2018, pp. 95-101. doi: 10.11648/j.ijfsb.20180303.14

Received: August 23, 2018; Accepted: September 18, 2018; Published: November 29, 2018

\begin{abstract}
The influence of different storage conditions (ambient temperature, refrigeration temperature, and hot air wooden cabinet storage) on nutrient retention capacity of onion bulbs was investigated. The fresh onions varieties (red and white) were obtained from a private farm (Modibbo Isah Farms, Bichi, Kano State, Nigeria). The experiment followed a completely randomized design in a factorial $3 \times 2 \times 8$, with a total of 48 treatments, corresponding to three storage temperature conditions, two onion varieties and eight-week storage duration. The storage temperature conditions were ambient temperature $\left(30 \pm 2^{\circ} \mathrm{C}\right)$, refrigeration storage $\left(5-7^{\circ} \mathrm{C}\right)$ and hot air wooden cabinet storage $\left(45-50^{\circ} \mathrm{C}\right)$ while the two onion varieties were white and red types. The prevailing relative humidity during the storage period ranged between 70 and $95 \%$. The result showed that some constituents of the stored onions decreased with increase in the storage period and this particularly occurred in moisture content (86.89$63.76 \%)$. Some parameters showed increased values with increase in the storage period and these include ash content $(0.98-$ $1.60 \%$ ), fat content (1.28-1.76\%), protein content (1.45-4.75\%), crude fibre content (0.96-1.74\%), and carbohydrate content (9.05$28.82 \%$ ). The onion types essentially exhibited diverse responses to these different storage conditions which might be linked to botanical diversity. However, the red onions seem to show greater stability in terms of nutrient retention than the white type while ambient temperature storage conditions may be regarded as the best of the three storage conditions investigated.
\end{abstract}

Keywords: Onion, Nutrient, Storage, Postharvest, Proximate Composition

\section{Introduction}

Onion is believed to originate from Asia but cultivated in most of the countries around the world [1]. Onion is primarily consumed as a spice in various dishes for unique flavour and pungent taste due to its volatile oil (allyl-propyl-disulphide) but also plays a significant role in human nutrition with medicinal properties [2]. The onion, either as mature bulb or green leaves, is popular for culinary purposes and is also a rich source of calcium, sodium, phosphorous, and fibre with no fat $[3,4]$. Epidemiological and clinical studies have shown that the nutritional consumption of this vegetable can help in the prevention and management of some diseases such as some forms of cancer, diabetes, peroxynitrite induced diseases, osteoporosis, cardiovascular diseases, tooth disorders, urinary infections, sexual debility, cholera, ear and skin disorder, cough, anemia, etc. [5].

In spite of high production output of onion in Nigeria coupled with its nutritional benefits, it has a short postharvest life resulting in high losses [6]. It has been estimated that the post-harvest losses of onion bulbs in the developing countries could be as high as $20-95 \%$ annually [7]. However, postharvest losses of 16-35\% had been reported [8]. Exact data on the nature and extent of these losses at each stage in the postharvest chain is not readily available in the literature. Postharvest losses could have serious economic impacts such as direct financial losses on the part of the growers and marketers. It also indicates a waste of productive agricultural resources such as land, water, labour, managerial skills and other inputs that have been channelled towards the production of the crop. In most developing countries, postharvest losses of food crops have been faulted as a major cause of food 
insecurity and food shortage.

Many scientific efforts have been made to extend the storage life of onions by way of reducing the water content of onions, which causes their high perishability. Drying of the onions for water reduction has therefore been the commonest approach to their preservation [9, 10]. The application of gammairradiation has also been applied to reduce pathogenic microflora in onions for their shelf life extension [11]. Another alternative method for preserving onions apart from storage conditions modification is the processing and drying of onions into powder form [12]. The objective of this study therefore was to evaluate the influence of different storage conditions (ambient temperature, refrigeration temperature, and hot air wooden cabinet storage) on nutrient retention capacity of onion bulbs.

\section{Materials and Methods}

\subsection{Source of Materials}

The fresh samples of red and white onion varieties were obtained from a private farm (Modibbo Isa Farm, Bichi, Nigeria), situated at longitude of $12^{\circ} 16^{\prime \prime} 53^{\prime \prime}$ North and latitude of $8^{\circ} 23 " 38^{\prime \prime}$ East. The samples were cured (air dried) for two weeks at the farm and then transported for analysis in the laboratory.

\subsection{Storage of Onions at Different Conditions}

The fresh onions were stored for two months during which the sample were analysed weekly under three different storage conditions which are: ambient temperature of $30 \pm 2^{\circ} \mathrm{C}$, refrigeration temperature of $5-7^{\circ} \mathrm{C}$, and hot air wooden cabinet storage at $45-50^{\circ} \mathrm{C}$.

Ambient temperature storage: In ambient temperature storage, the fresh onions were stored under two different storage cupboards at $30 \pm 2^{\circ} \mathrm{C}$. One cupboard contained carefully selected 45 pieces of red onions while the second cupboard also contained 45 pieces of white onions. The cupboards were made from plywood material and all the sides had sizeable openings and covered with wire gauze to allow adequate ventilation. The dimensions of the cupboards were 2 $\mathrm{m}$ length, $1.5 \mathrm{~m}$ height and $1 \mathrm{~m}$ breadth.

Refrigeration temperature storage: Under refrigeration temperature storage, the fresh onions were stored under two different fridges at $5-7^{\circ} \mathrm{C}$. One fridge was made to store 45 pieces of red onions and the other fridge also contained 45 pieces of white onions at the same storage temperature.

Hot air wooden cabinet storage: In the hot air wooden cabinet storage, the fresh onions were stored at $45-50^{\circ} \mathrm{C}$. One cupboard contained 45 pieces of red onions and the other also contained 45 pieces of white onions. The temperature of 45$50^{\circ} \mathrm{C}$. was maintained within the cupboard with electric bulbs and the internal temperature of the cupboards was measured by thermometers. The cupboards were constructed with plywood materials having some holes by the sides to allow gaseous exchange within the produce. The dimension of each the two cupboards were $2 \mathrm{~m}$ length, $1.5 \mathrm{~m}$ height and $1 \mathrm{~m}$ breadth.

\subsection{Determination of Proximate Composition of Stored Onions}

The proximate composition of the samples was carried out using the standard procedures [13].

Moisture content determination: Samples of clean flat platinum dish were oven dried at $105^{\circ} \mathrm{C}$ and cooled in a desiccator. The cooled dishes were weighed (W1). Five grammes $(5 \mathrm{~g})$ of each onion type were introduced into the dish and weighted accurately (W2). The dish and its content were transferred into an air oven at $105^{\circ} \mathrm{C}$ to dry for about 3 hours. The dishes were returned to the oven for half an hour and again, cooled in the desiccators and weighed. The process was repeated till a constant weight (W3) was attained. Percentage moisture content was calculated as follows:

$$
\text { Moisture }(\%)=\left(W_{2}-W_{3}\right) /\left(W_{2}-W_{1}\right) \times 100
$$

This value is the same as $\%$ loss on drying $/ \%$ matter volatile at $105^{\circ} \mathrm{C}$

Where,

$\mathrm{W} 1=$ weight of petri dish

$\mathrm{W} 2=$ weight of petri dish + sample before drying.

W3 = weight of petri dish + sample after drying.

Ash content determination: Clean silica dishes were dried and cooled in a desiccator prior to weighing (W1). Five grammes $(5 \mathrm{~g})$ of each onion type were weighed accurately and placed in the dish (W2). Thereafter, the dish was transferred by using a pair of tongs into a muffle furnace for ashing at $500^{\circ} \mathrm{C}$ until fully ashed (grey colour ash). The ashed sample was cooled in desiccators and weighed (W3). The percent ash content was calculated as follows:

$$
\operatorname{Ash}(\%)=\left(W_{3}-W_{1}\right) /\left(W_{2}-W_{1}\right) \times 100
$$

Where,

$\mathrm{W} 1$ = weight of crucible

W2 $=$ weight of crucible + sample before ashing

W3 = weight of crucible + sample after ashing

Determination of fat content: Five grammes $(5 \mathrm{~g})$ of each onion type were accurately weighed $(\mathrm{W})$ using a weighing balance. A clean flat bottomed flask was weighed (W1) and the extractor was mounted on it. The thimble was held half way into the extractor and weighed sample were transferred into the thimble. The weighed dishes were rinsed with the solvent (petroleum ether) which was poured into the thimble and the thimble was cotton plugged. The solvent was made to reach about two third of the volume of the flask and continuous reflux of the solvent was allowed for five hours to enable fat extraction. After extraction, the solvent left in sample was made to evaporate in the oven and the flask and the residue was cooled and weighed (W2). The fat content was calculated as follows:

$$
\text { Fat }(\%)=\left(W_{2}-W_{1}\right) / W \times 100
$$

Determination of nitrogen and crude protein: Five grammes $(5 \mathrm{~g})$ of each onion type were weighed and transferred into a Kjedahl flask. Using a measuring cylinder, about $15 \mathrm{ml}$ concentrated sulphuric acid and one tablets of kjeldhal catalyst 
were added to the flask. The flask in an inclined position was gently heated in a fume cupboard, using heating mantle. When the initial vigorous reaction has subsided, the heat was increased and digestion was continued until the liquid was clear and free from black or brown colour. The flask was allowed to cool and the mixture was transferred to $100 \mathrm{ml}$ volumetric flask, and diluted with distilled water to the mark. About $10 \mathrm{ml}$ of the sample aliquot and $15 \mathrm{ml}$ of $40 \%$ sodium hydroxide solution was transferred into the distillation apparatus consisting of the flask (500 $\mathrm{ml}$ capacity), stopper carrying a dropping funnel and a splash head adaptor: a vertical condenser. Ten millilitres $(10 \mathrm{ml})$ of $2 \%$ boric acid solution was measured into a $250 \mathrm{ml}$ conical flask, and a few drops of screened methyl red indicator were added to the flask and then placed on the receiver so that the end of the delivery tube is below the level of the boric acid. A few pieces of granulated zinc and some anti-dumping granules were added to the distillation flask. The apparatus were shaken gently to ensure thorough mixing of the contents. The flask was boiled vigorously until about $25 \mathrm{ml}$ distillate is obtained. The receiver was removed and titrated against a standard acid $0.025 \mathrm{M}$ $\mathrm{H}_{2} \mathrm{SO}_{4}$ till a pink colour end point (TV) is reached. The nitrogen content of the samples was calculated as follows:

$$
N(\%)=(0.014 \times T V \times 100 \times 0.025) /(W \times 10) \times 100
$$

Where,

$\mathrm{W}$ is weight of sample taken.

$\%$ Crude protein $=\mathrm{N} \times \mathrm{F}$.

Where, $\mathrm{F}=6.25$.

Determination of crude fibre: Five grammes $(5 \mathrm{~g})$ of each onion type were weighed (W1) and defatted by ether extraction with Soxhlet apparatus and dried. The sample was transfered quantitatively by brushing in a $600 \mathrm{ml}$ beaker of the fibre digestion apparatus. Exactly $200 \mathrm{ml}$ of $1.25 \%$ sulphuric acid was added. The beaker were placed on digestion apparatus with pre- adjusted heater and boiled for exactly 30 minutes. The beaker was removed and the contents were filtered through California Buchner funnel. The beaker was rinsed with $75 \mathrm{ml}$ of boiling water and washed through the funnel. The washing was repeated 3 times with $50 \mathrm{ml}$ portion of water and then sucked dry. The residue was returned to the beaker by blowing back through the funnel. Exactly $200 \mathrm{ml}$ of hot $1.25 \%$ sodium hydroxide was added to the beaker and boiled for 30 minutes and the beaker was removed and filtered. The residue was then washed with $25 \mathrm{ml}$ of hot $1.25 \%$ sulphuric acid, followed by three $50 \mathrm{ml}$ portion of water and $25 \mathrm{ml}$ of alcohol respectively. The fibre mat and the residue were then dried at $130 \pm 2$ oC for 2 hours. It was then cooled in a desiccator and weighed (W2). It was then ignited at $600 \pm 15^{\circ} \mathrm{C}$ for 30 minutes in a muffle furnace. The dishes were removed and cooled in a desiccator and weighed (W3). The crude fibre was calculated as follows:

$$
\text { (\%) Crude fibre }=\left(W_{2}-W_{3}\right) /\left(W_{1}\right) \times 100
$$

Where

$\mathrm{W} 1$ = weight of sample

$\mathrm{W} 2$ = weight of crucible + sample after drying
W3=weight of crucible + sample after ashing

Determination of carbohydrate: Total carbohydrate was calculated by difference using the following formula:

Carbohydrate $(\%)=100-(\%$ Moisture $+\%$ Ash $+\%$ Fat $+\%$ Protein $+\%$ Crude fibre).

\section{Results and Discussion}

\subsection{Effect of Storage Conditions on the Moisture Content of Onion Types}

Figure 1 shows the moisture content of stored onions subjected to three different storage conditions. Some of the onion samples, WO-AT, WO-HT, RO-AT and RO-HT were observed to decrease in moisture content when initial and final values were compared. However, during the course of storage, the onions exhibited an oscillating trend in their moisture content changes at $70-95 \%$ relative humidity. The trends of changes in the moisture content for the samples within the eight-week storage duration were: $86.89-66.76 \%$ (WO AT), $86.09-93.18 \%$ (WO -RT), $86.14-63.37 \%$ (WO -HT), 88.61 - 68. 95\% (RO - AT), 88.06 - 93.18\% (RO - RT), and $88.84-63.76 \%$ (RO - HT). In the case of RO-RT and WO-RT samples, the onions exhibited an increase in the moisture content when compared with the values of fresh samples. The increase in the moisture content of (RO - RT) and (WO - RT) samples may be due to the water absorption in the refrigeration while the decrease in $(\mathrm{WO}-\mathrm{AT}),(\mathrm{WO}-\mathrm{HT}),(\mathrm{RO}-\mathrm{AT})$ and (RO - HT) samples, respectively may be attributed to the effect of higher temperature which increased the rate of water loss during the storage period coupled with respiration process in the samples. Yahaya et al. [14] and Bhattacharjee et al. [15] similarly observed a decrease in the moisture content of onions under ambient storage condition and an increase in moisture content under refrigeration storage while Sangwan et al. [16] observed a decrease in the moisture content for all storage conditions.

\subsection{Effect of Storage Conditions on the Ash Content of Onion Types}

Figure 2 shows the ash content of stored onions in three different storage conditions. Some of the onions (WO-AT, WO-HT, RO-AT, and RO-HT) exhibited an increase in the ash content during the storage period with increase in storage duration while some (WO-RT and RO-RT) exhibited a decrease. The ranges of ash content variation during the eightweek storage period were as follows: $0.98-1.60 \%$ (WO -AT), $1.02-1.68 \%$ (WO - HT), 1.12-1.56\% (RO - AT), and $0.98-$ $1.60 \%(\mathrm{RO}-\mathrm{HT})$. The samples that showed a decrease in ash content were WO - RT (0.92-0.76\%) and RO - RT (1.11$0.74 \%$ ). Some previous researchers had similarly observed a decrease in ash content under refrigeration condition as well as an increase under ambient temperature storage [14-17]. The increase in the ash contents of onion samples particularly under ambient and high temperature storage may be attributed to possible decrease in the moisture content of the onions which might have led to the seeming concentration of the constituents 
of the samples. The decrease in the ash content of some of the samples especially those under refrigeration conditions may also be due to possible moisture increase which might have caused seeming dilution of the constituents of the samples.

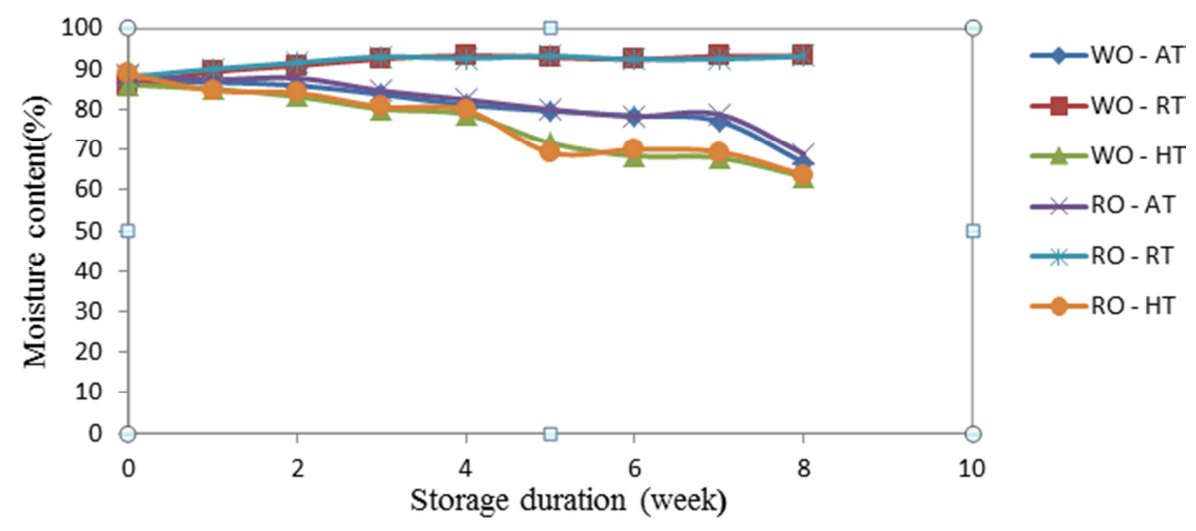

Figure 1. Changes in moisture content of onion types at different storage conditions.

Key: WO $-\mathrm{AT}=$ White onion stored at ambient temperature $\left(30 \pm 2^{\circ} \mathrm{C}\right)$; WO $-\mathrm{RT}=$ White onion stored at refrigeration temperature $\left(5-7^{\circ} \mathrm{C}\right)$; WO $-\mathrm{HT}=\mathrm{White}$ onion stored in wooden cabinet $\left(45-50^{\circ} \mathrm{C}\right)$; RO $-\mathrm{AT}=\mathrm{Red}$ onion stored at ambient temperature $\left(30 \pm 2^{\circ} \mathrm{C}\right)$; RO $-\mathrm{RT}=\mathrm{Red}$ onion stored at refrigeration temperature $\left(5-7^{\circ} \mathrm{C}\right) ; \mathrm{RO}-\mathrm{HT}=\operatorname{Red}$ onion stored in wooden cabinet $\left(45-50^{\circ} \mathrm{C}\right)$.

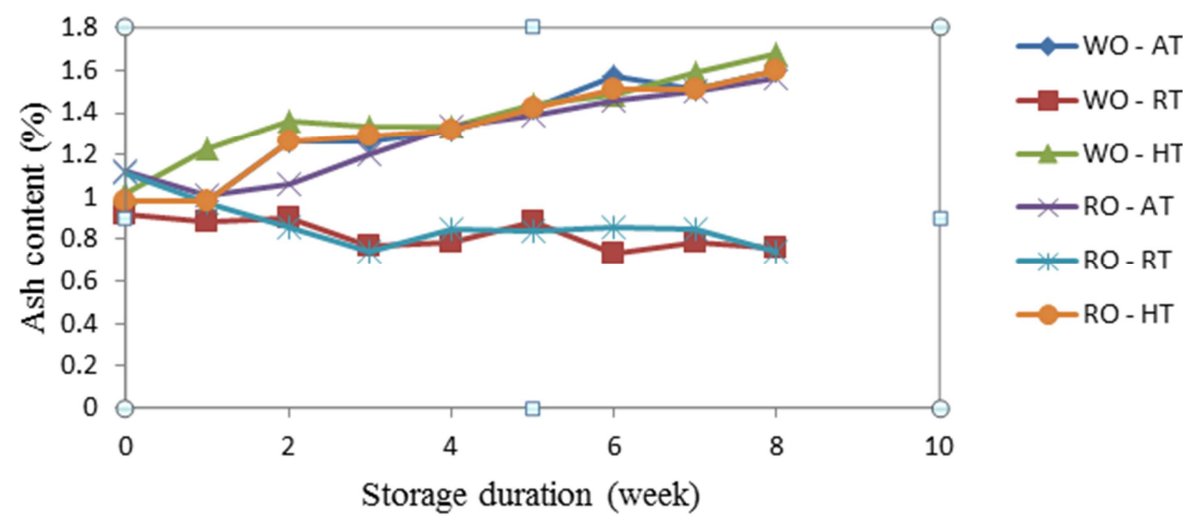

Figure 2. Changes in ash content of onion types at different storage conditions.

Key: WO $-\mathrm{AT}=$ White onion stored at ambient temperature $\left(30 \pm 2^{\circ} \mathrm{C}\right)$; WO $-\mathrm{RT}=$ White onion stored at refrigeration temperature $\left(5-7^{\circ} \mathrm{C}\right)$; WO $-\mathrm{HT}=\mathrm{White}$ onion stored in wooden cabinet $\left(45-50^{\circ} \mathrm{C}\right)$; RO $-\mathrm{AT}=\mathrm{Red}$ onion stored at ambient temperature $\left(30 \pm 2^{\circ} \mathrm{C}\right)$; RO $-\mathrm{RT}=\mathrm{Red}$ onion stored at refrigeration temperature $\left(5-7^{\circ} \mathrm{C}\right) ; \mathrm{RO}-\mathrm{HT}=\operatorname{Red}$ onion stored in wooden cabinet $\left(45-50^{\circ} \mathrm{C}\right)$.

\subsection{Changes in the Fat Content of Onion Types as Influenced by Storage Conditions}

Changes in the fat contents of stored onions in three different storage conditions are shown in Figure 3. It was observed that there was no specific pattern of changes in the fat content during the storage period as a decrease or increase in fat content was seen to be oscillating. In the case of RO-HT sample, the ash content increased up to the $3 \mathrm{rd}$ week of storage $(0.93-1.58 \%)$ and thereafter got decreased up to the 5 th week $(1.58-1.13 \%)$ before it started to increase again up to the 8 th week of storage (1.13-1.76\%). The increase and decrease in fat content may be attributed to water loss during the storage period in the case of ambient and high temperature storage coupled with possible fat loss itself through hydrolytic reaction in the samples. This might have led to the complexity of increase-decrease pattern in the fat content of the onion types. It had earlier been observed that certain enzymes do get activated during onion storage [18]. This trend was not in conformity with the observation of Wardlaw el al. [19] who noted an increase in fat content under ambient storage condition and a decrease under refrigeration storage conditions while Falayi el al. [20] observed a decrease for all storage conditions.

\subsection{Changes in the Protein Content of Onion Types as Influenced by Storage Conditions}

The changes in protein content of stored onions subjected to three different storage conditions are shown in Figure 4. All the onions showed an increase in the protein content when compared with the values of fresh samples. However, during the course of storage, the onions generally exhibited an oscillating trend in their protein values. Both onion types showed an increase in protein content across the storage period. The increase in protein content during refrigeration storage period could be due to fungal attack in the onion bulbs as the increase in protein content of refrigerated onions may include microbial protein. This is because the onion bulbs 
showed an evidence of fungal growth on the bulbs. However, the increase in the protein content of other storage conditions (ambient temperature and wooden cabinet storage) may be due to decrease in the moisture of the onion bulbs that might have concentrated the protein.

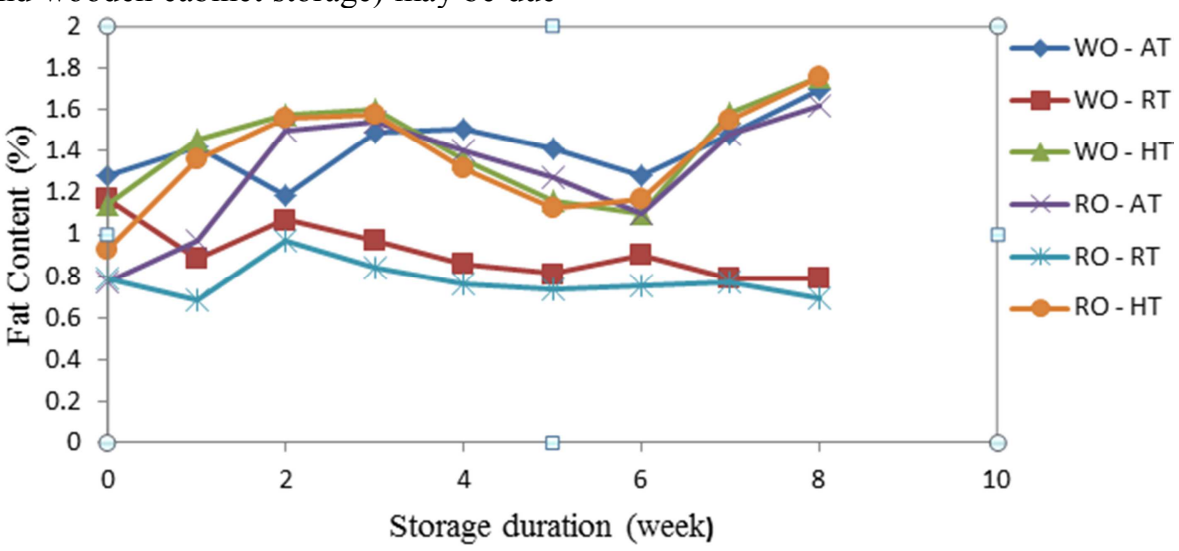

Figure 3. Changes in fat content of onion types at different storage conditions.

Key: WO $-\mathrm{AT}=$ White onion stored at ambient temperature $\left(30 \pm 2^{\circ} \mathrm{C}\right)$; WO $-\mathrm{RT}=$ White onion stored at refrigeration temperature $\left(5-7^{\circ} \mathrm{C}\right)$; WO $-\mathrm{HT}=\mathrm{White}$ onion stored in wooden cabinet $\left(45-50^{\circ} \mathrm{C}\right)$; RO $-\mathrm{AT}=\mathrm{Red}$ onion stored at ambient temperature $\left(30 \pm 2^{\circ} \mathrm{C}\right)$; RO $-\mathrm{RT}=\mathrm{Red}$ onion stored at refrigeration temperature $\left(5-7^{\circ} \mathrm{C}\right)$; $\mathrm{RO}-\mathrm{HT}=\mathrm{Red}$ onion stored in wooden cabinet $\left(45-50^{\circ} \mathrm{C}\right)$.

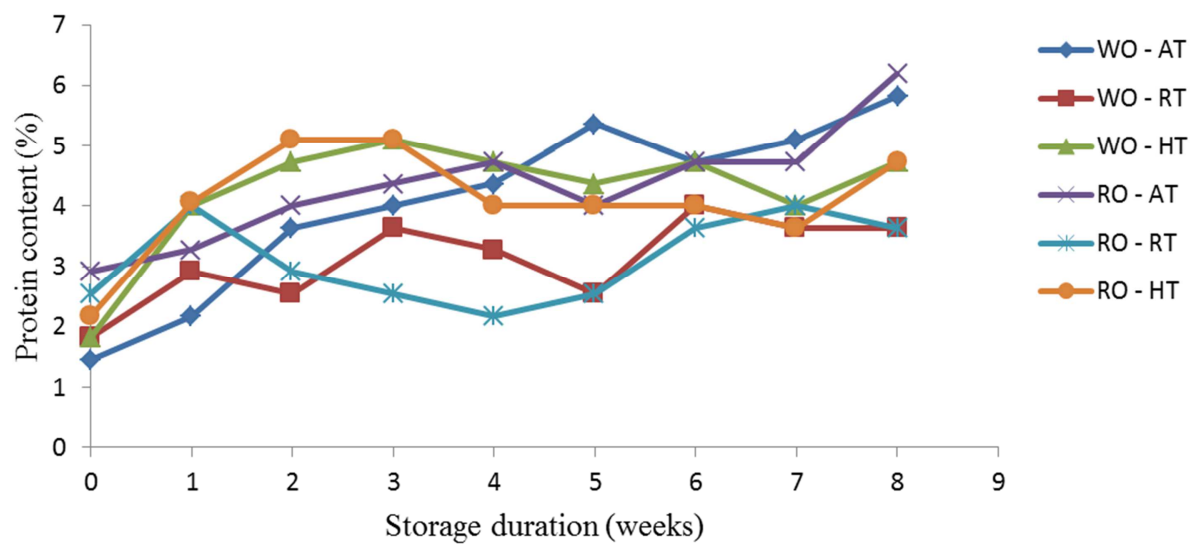

Figure 4. Changes in protein content of onion types at different storage conditions.

Key: $\mathrm{WO}-\mathrm{AT}=$ White onion stored at ambient temperature $\left(30 \pm 2^{\circ} \mathrm{C}\right)$; WO $-\mathrm{RT}=$ White onion stored at refrigeration temperature $\left(5-7^{\circ} \mathrm{C}\right)$; WO $-\mathrm{HT}=\mathrm{White}$ onion stored in wooden cabinet $\left(45-50^{\circ} \mathrm{C}\right)$; RO $-\mathrm{AT}=$ Red onion stored at ambient temperature $\left(30 \pm 2^{\circ} \mathrm{C}\right)$; RO $-\mathrm{RT}=\mathrm{Red}$ onion stored at refrigeration temperature $\left(5-7^{\circ} \mathrm{C}\right)$; $\mathrm{RO}-\mathrm{HT}=$ Red onion stored in wooden cabinet $\left(45-50^{\circ} \mathrm{C}\right)$.

The increase in protein content during storage was found to be similar to the reports of Wardlaw et al. [19] and Yahaya et al. [14] which also observed an increase in the protein content of onions under ambient storage.

\subsection{Changes in the Crude Fibre Content of Onion Types as Influenced by Storage Conditions}

The result of the crude fibre is presented in Figure 5. The result showed that samples WO-AT, WO-HT, RO-AT and ROHT exhibited a general increase in the crude fibre content with respect to the final value at the end of storage period although oscillating changes in the crude fibre was experienced during the storage period. For samples WO-RT and RO-RT, the final crude fibre at the end of the storage period was lower than that of the fresh. The decrease in crude fibre content in refrigeration condition storage may be as a result of fungal degradation during the storage period. An earlier observation had revealed that there are diverse fungal pathogens like Aspergillus spp,
Penicillium spp, Alternaria spp, Fusarium spp, Rhizopus spp., Colletotrichum spp., Pseudomonas spp., Lactobacillus spp., Erwinia spp., and Botrytis spp which attack onion bulbs during the post-harvest storage period [21]. The crude fibre content of stored onions, under ambient storage conditions, showed a decrease-increase trend. This observation is similar to the results obtained by Ponnusamy and Vellaichamy [22] while Ayoola et al. [23] observed an increase in the crude fibre under refrigeration storage.

\subsection{Changes in the Carbohydrate Content of Onion Types as Influenced by Storage Onditions}

Figure 6 shows the changes in carbohydrate content of stored onions at three different storage conditions. Some of the samples WO-AT, WO-HT, RO-AT, and RO-HT exhibited an increase in the carbohydrate content during the storage period when compared with the fresh values, although oscillating changes in the carbohydrate content was experienced during 
the storage period. In the case of RO-AT samples, the carbohydrate content increased up to the 2 nd week of storage $(7.26 \%)$ and thereafter got decreased up to the 3 rd week $(5.60 \%)$ before is started to increase again up to the 8 th week of storage $(21.65 \%)$. In the case of WO-RT and RO-RT, the final values of carbohydrate content at the end of the storage period were lower than that of the fresh values. The decrease in the carbohydrate content of refrigerated onions may be as a result of increase in moisture content thereby causing seeming dilution of the onion constituents. The decrease in the carbohydrate content of onions during storage may be attributed to a general degradation of the organic matter of onions and the onset of processes of conversion of organic substances to volatile compounds which get intensified during storage and sprouting [18]. The observed trend of a decrease in the carbohydrate content of onions under refrigeration storage and increase in the carbohydrate content of onions under ambient storage as noted during the storage period is similar to the results obtained in other studies by Mouluda et al. [24] while Ayoola et al. [23] also observed a decrease in the carbohydrate content under ambient storage.

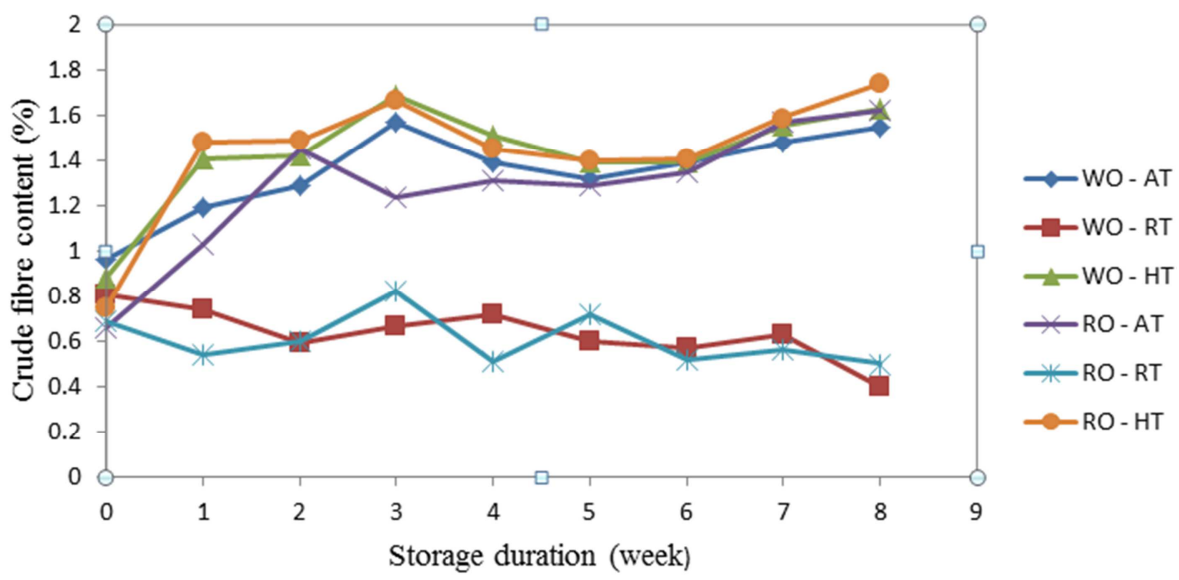

Figure 5. Changes in crude fibre content of onion types at different storage conditions.

Key: WO $-\mathrm{AT}=$ White onion stored at ambient temperature $\left(30 \pm 2^{\circ} \mathrm{C}\right)$; WO $-\mathrm{RT}=$ White onion stored at refrigeration temperature $\left(5-7^{\circ} \mathrm{C}\right)$; WO $-\mathrm{HT}=\mathrm{White}$ onion stored in wooden cabinet $\left(45-50^{\circ} \mathrm{C}\right)$; RO $-\mathrm{AT}=\mathrm{Red}$ onion stored at ambient temperature $\left(30 \pm 2^{\circ} \mathrm{C}\right)$; $\mathrm{RO}-\mathrm{RT}=\mathrm{Red}$ onion stored at refrigeration temperature $\left(5-7^{\circ} \mathrm{C}\right)$; RO $-\mathrm{HT}=$ Red onion stored in wooden cabinet $\left(45-50^{\circ} \mathrm{C}\right)$.

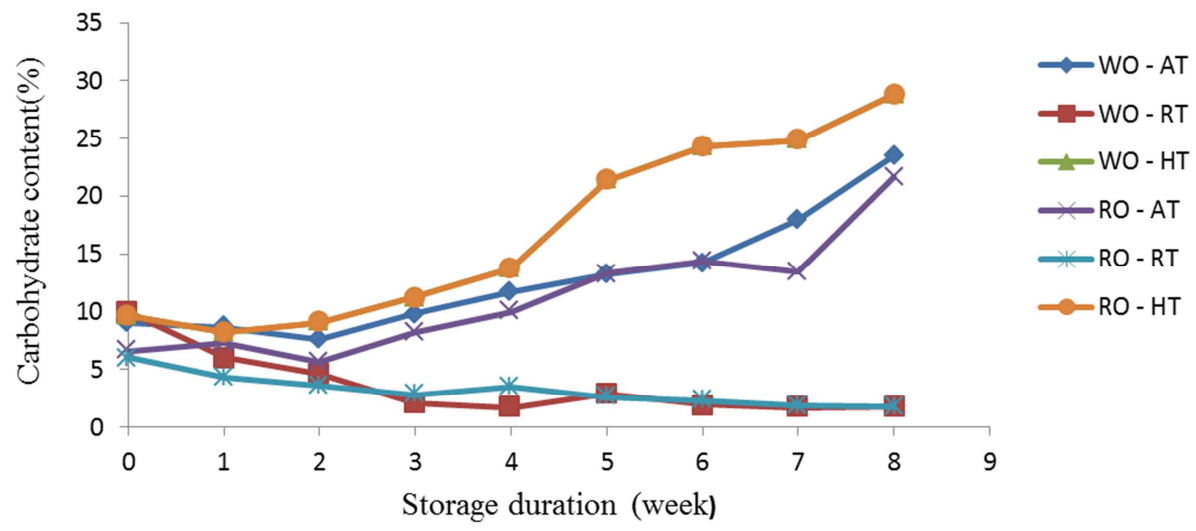

Figure 6. Changes in carbohydrate content of onion types at different storage conditions.

Key: $\mathrm{WO}-\mathrm{AT}=$ White onion stored at ambient temperature $\left(30 \pm 2^{\circ} \mathrm{C}\right)$; WO $-\mathrm{RT}=$ White onion stored at refrigeration temperature $\left(5-7^{\circ} \mathrm{C}\right)$; WO $-\mathrm{HT}=\mathrm{White}$ onion stored in wooden cabinet $\left(45-50^{\circ} \mathrm{C}\right)$; RO $-\mathrm{AT}=\mathrm{Red}$ onion stored at ambient temperature $\left(30 \pm 2^{\circ} \mathrm{C}\right)$; $\mathrm{RO}-\mathrm{RT}=\mathrm{Red}$ onion stored at refrigeration temperature $\left(5-7^{\circ} \mathrm{C}\right)$; RO $-\mathrm{HT}=$ Red onion stored in wooden cabinet $\left(45-50^{\circ} \mathrm{C}\right)$.

\section{Conclusion}

It may be concluded that subjecting onion bulbs to different storage conditions such as ambient temperature, refrigeration temperature, and hot air wooden cabinet storage; had led to variations in the nutrient retention capacity of the onion types. The onion types essentially exhibited diverse responses to these different storage conditions which might be linked to botanical diversity. However, the red onions seem to show greater stability in terms of nutrient retention than the white type while ambient temperature storage conditions may be regarded as the best of the three storage conditions investigated.

\section{Acknowledgements}

The authors wish to express their gratitude to the management of Modibbo Isah Farms, Bichi, Kano State, Nigeria; for the supply of the onion types used in this study. 


\section{References}

[1] Kukanoor, L. (2005). Postharvest studies in onion. Department of Horticulture, College of Agriculture, Dharwad University of Agricultural Sciences, Dharwad, pp 19-144.

[2] Randle, W. M. (2000). Increasing nitrogen concentration in hydroponic solutions affects onion flavour and bulb quality. Journal of the American Society for Horticultural Science, 125: 254-259.

[3] Nayerabi, S. A. F. and Ahmed, A H M. (2001). The commercial vegetable of Pakistan. Tropical Science, 41: 95-99.

[4] Marwat, S. K., Rehman, F., Khan, M A., Ahmad, M., Zafar, M. and Ghulam, S. (2011). medicinal folk recipes used as traditional phytotherapies in District Dera Ismail Khan, Pakistan. Pakistan Journal of Botany, 43: 1453-1462.

[5] Nath, K. V. N., Rao, K. N. V., Banji, D., Sandhya, S., Sudhakar, K., Saikumar, P., Sudha, P. and Chaitanya, R. K. (2010). Onion (Allium cepa) - Ethnomedicinal and therapeutic properties. Journal of Advance Pharmacetical Residue, 1 (2): 94-100.

[6] Shankara N., Maijade G., Matin H. and Van Dam B. (2005). Cultivation of tomato, production, processing and marketing. Digigrafi Press, Wangeningen, the Netherlands.

[7] Anon, (2000). Report of the Steering Committee on Postharvest Food Losses in Developing Countries. National Research Council, National Science Foundation, Washington DC.

[8] Steppe, H. M. (1976). Post harvest losses of agricultural products. Report. WP/225176 Serial No. 240. United Nations Development Programme, Teheran, Iran. Pp. 227-229.

[9] Kumar, D. G. P., Hebbar, H U., Sukumar, D. and Ramesh, M N. (2005). Infrared and hot - air drying of onions. Journal of Food Processing and Preservation, 29 (2): 132-150.

[10] Mota, C. L., Luciano, C., Dias, A., Barroca, M. J., Guiné, R P F. (2010). Convective drying of onion: Kinetics and nutritional evaluation. Food and Bioproducts Processing, 88 (2-3): 115-123.

[11] Abdullah R., Farooq, A., Qaiser, H., Iqtedar, M., Kaleem, A. and Naz, S. (2018). Enhancement of safety and quality of allium cepa by optimizing gamma radiation dose enduring reduction of pathogenic microflora. FUUAST Journal of Biology, 8 (1): 95102.

[12] Kang, N. S. Kim, J H. and Kim, J. K. (2007). Modification of quality characteristics of onion powder by hot-air, vacuum and freeze drying methods. Korean Journal of Food Preservation, 18: $1-5$.

[13] AOAC (1990). Association of Official Analytical Chemists. Official Method of Analysis, $15^{\text {th }}$ edition.

[14] Yahaya, Y. Birnin, Y. U. A, and Badu do, B U. (2010). Study of nutrient content variation in bulb and stalk of onions (Allium cepa L.) cultivation in Aliero, Kebbi State, Nigeria. Bulgarian Journal of Basic and Applied Science, 18 (1): 83-89.

[15] Bhattacharjee, S., Sultana, A., Sazzad, M H, Islam, M A., Ahtashom, M. and Asaduzzaman, M. (2013). Analysis of the proximate composition and energy values of two varieties of onion (Allium cepa L.) bulbs of different origin: A comparative study. International Journal of Nutrition and Food Science, 2 (5): $246: 253$

[16] Sangwan, A., Kawatra, A. and Sehgal, S. (2010) Nutritional evaluation of onion powder dried using different drying methods. Journal of Dairying, Foods and H S., 29 (2): 151-153.

[17] Edeogu, C. O., Ezeonu, F. C., Okaka, A. N. C., Ekuma, C. E., and Elom, S. O. (2007). Proximate composition of staple food crops in Ebonyi State (South Eastern Nigeria). International Journal of Biotechnology and Biochemistry, 3 (1): 1-8.

[18] Sharma, K. and Lee, Y. (2016). Effect of different storage temperature on chemical composition of onion (Allium cepa L.) and its enzymes. Journal of Food Science and Technology, 53 (3): $1620-1632$.

[19] Wardlaw, G. M. and Kessel, M. (2002). Prospective in Nutrition, $5^{\text {th }}$ edition, Boston: McGraw-Hill, Pp. 278.

[20] Falayi, F R. and Yusuf, H A. (2014). Performance evaluation of a modified onion storage structure. Journal of Emerging Trends in Engineering and Applied Science-(JETEAS), 5 (5): 334-339.

[21] Kumar, V., Neeraj, S S. and Sagar, N A. (2015). Postharvest management of fungal diseases in onion - A Review. International Journal of Current Microbiology and Applied Sciences, 4 (6): 737-752.

[22] Ponnusamy, S. and Vellaichamy, T. (2012). Nutritional assessment, polyphenols evaluation and antioxidant activity of food resource plant Decalepis hamiltonii Wight \& Arn," Journal of Applied Pharmaceutical Science, 2 (5): 106-110.

[23] Ayoola, O. (2014). Hot air drying and quality of red and white varieties of onion (Allium cepa). Journal of Agriculture Chemistry and Environment, 3: 13-19.

[24] Mouluda, S. Kamal, U. S. and Mahomud, S. (2016). Physiological change in red onion bulb at different storage temperature. World Journal of Engineering and Technology, 4: 261-266. 